this is rather the character of English-grown Cedar than of timber which has come to maturity in its native moun. tains."

I do not find that I often differ from Johns, but in this case $I$ am afraid that he is quite wrong. The quality and durability of English-grown cedar is in every way as good as that produced elsewhere, and the aromatic scent is persistent-undeniable facts which can be proved.

The forests of cedars on Mt. Lebanon, which were known to the civilized world nearly two thousand years ago, have gone. The Rev. C. A. Johns, in 1849, quotes Maundrell as follows, who measured the largest cedar on Mt. Libanus :

"I found it 12 yards 6 inches in girth and yet sound, and 37 yards in the spread of its boughs."

To-day the traveller would have difficulty in counting a score still remaining. This is a terrible illustration of the destruction of forests with the march of civilization. From every quarter of the globe, whichever way we turn, we are confronted with the same story.

Dr. Fosdick, in a book entitled "A Pilgrimage to Palestine", says, speaking of the country between Samaria and Galilee, and the Plain of Sharon by the sea :

"Whether or not there used to be more trees upon these hills than now has often been discussed, but I do not see how anyone can doubt it. In this last war alone (19141918) it is estimated that 40 per cent of all the olive trees in Palestine were cut down for military purposes. To say nothing of the locusts, two great enemies of the trees have ravaged the land for centuries-Militarists and goats. . . . When Pompey came to take Palestine for Rome, the record says that he cleared away the trees, and Josephus tells us that Titus cut down every tree within ten miles of Jerusalem. ... Even in the Lebanons they are finding boundary stones set by Hadrian's foresters-I saw one in Beirut-where to-day only bare mountains remain. The forest of Hereth, where David hid, is gone; there is no forest of Bethal to shelter bears to-day; Kiriath-jearim, which means 'city of forests', would have no excuse now for such a name, and the woods of Sharon, which Strabo called 'a great forest', and which once stretched from the valley of Ajalon up to Mount Carmel, now have few relics of their ancient glory."

We should indeed be a decadent people if we allowed a thing of such beauty and interest as the cedar tree to vanish from our landscape.

\section{ANTIBACTERIAL SUBSTANCES IN GREEN PLANTS}

$\mathrm{F}$ ROM the earliest times, writes E. M. Osborn (Brit. J. Exp. Path., 24, 227; 1943), plants have been used in the attempt to cure disease. After giving a brief summary of recent work on the well-known occurrence of antibacterial substances in green plants, he records the results of his own investigation of about 2,300 different green plants, most of them flowering plants. All the plants used were freshly picked and all available parts of them were tested. The method of testing used was the diffusion method of Abraham and other Oxford workers (The Lancet, ii, 177 ; 1941), the antibacterial substance being tested against Staphylococcus aureus and Bacterium coli. The test shows only the presence or absence of the antibacterial substance and is not quantitative. A negative result does not necessarily prove the absence of the antibacterial substances, and the possibility of their destruction by enzymes must also be remembered.

At the time when this paper was written, antibacterial substances had been found in sixty-three genera of plants belonging to twenty-eight families. Extracts from plants belonging to the same families tend to show similar specificity and potency. Inhibiting substances are distributed throughout some plants (for example, Asarum europceum (Asarabacca)). In others their distribution is restricted. There is more of them in the seeds of Brassica oleracea (cabbage) than in other parts of this plant, and they were found only in the bark of Magnolia acuminata. This restricted distribution, together with differences in method of testing, may account for some negative results obtained with plants from which other workers have obtained bactericidal effects (for example, Chelidonium majus (greater celandine) and the turmip and horse radish). In many plants the inhibitory substances are produced by enzyme action ; for example, Plumeria bicolor, Cheiranthus cheiri (wall. flower) and Crepis taraxacifolia (hawk's-beard). In some instances the inhibitory substance is produced by the action of an enzyme situated in one part of the plant on an inactive precursor situated in another part of it. The drying of some plants causes loss of inhibitory power, for example, Clematis, Anemone, Ranunculus ; but the drying of others does not (for example, Crepis taraxacifolia (hawk's-beard), Reseda lutea (wild mignonette) and Asarum europoum). Certain well-known drug plants (Atropa, Datura, Digitalis) show no inhibitory power against the organisms used, nor do many plants recommended by herbalists.

A table shows the species from which "frankly positive" results were obtained. A feature of it is the activity of the Ranunculaceæ tested, some of which (for example, Anemone, Clematis, Helleborus and Ranunculus) inhibit both $\boldsymbol{S}$. aureus and Bact. coli. Extracts of some plants inhibit only $S$. aureus. Two of the plants tested were specific against Bact. coli. A full list of the species tested and the results obtained may be obtained from the Sir William Dunn School of Experimental Pathology, Oxford, and a similar list has been deposited in the archives of the Royal Society at Burlington House, London.

\section{FREQUENCY PERFORMANCE OF QUARTZ PLATES}

A $\mathrm{N}$ article by W. P. Mason (Bell Lab. Rec., 22, $A$ No. 6; February 1944) discloses some of the results of researches carried out to determine the frequency performance of quartz plates cut and oriented in a variety of ways. The natural frequencies depend largely on the plate dimensions and orientation with respect to the faces and angles of the original crystal, and on temperature.

Rectangular co-ordinates $x, y, z$, were used for specifying the manner of cutting. The $z$, or optical axis, runs vertically up the centre of the hexagonal prism assumed by the crystal ; the $y$, or mechanical, axis is taken perpendicular to any one of the three pairs of opposite faces ; and the $x$, or electrical, axis runs horizontally through opposite edges of the crystal. The first crystals used were known as $x$-cut and $y$-cut. Both have their width parallel to the 
$z$-axis, but the $x$-cut has its face perpendicular to the $x$-axis and its length parallel to the $y$-axis, while the $y$-cut has its face perpendicular to the $y$-axis, and its length parallel to the $x$-axis. For the $x$-cut crystal the voltage is applied along the electrical axis, and the vibration occurs parallel to the mechanical axis; the frequency is a function chiefly of the crystal length. For the $y$-cut crystal, the voltage is applied along the mechanical axis; voltages appear along this axis when the applied pressure is at $45^{\circ}$ to the mechanical and electrical axes, and thus, when voltage is applied along the $y$-axis, the vibration is one of shear.

The factors that make it desirable to seek other forms of cuts may be illustrated with the $x$-cut crystal in which, when voltage is applied along the electrical axis, the vibration is along the mechanical axis. Motion along the electrical axis also gives a displace. ment of charge along the electrical axis, and thus the $x$-cut crystal could vibrate in either direction; but the vibration frequeney, which will be determined chiefly by the dimension of the crystal in the direction of its vibration, will be much lower when the vibration is along the $y$-axis than when it is along the $x$-axis. As used, a voltage frequency was applied corresponding to the length vibration, and thus was comparatively low. If an effort were made to use the crystal for a high frequency, utilizing vibration along the $x$-axis, difficulties would occur because harmonics of the $y$-axis frequency might be very close to the $x$-axis frequency, and slight changes in conditions might cause the controlling vibration to shift from that of the $x$-frequency to a harmonic of a $y$-frequency.

The most common of such changes of conditions is the temperature, since the frequency of the $x$-cut crystal, and of the $y$-cut, is very sensitive to temperature changes. With a crystal of zero temperature coefficient, the frequency can be held to almost negligible variations by maintaining the crystal at the proper temperature. Accurate temperature control apparatus, however, is necessary when high constancy of frequency is desired. It would be very desirable if a crystal cut were available that had a zero temperature coefficient over a wide range of temperature, since this would make temperature control unnecessary over this range. Search for such a cut resulted in a crystal having a temperature coefficient essentially zero from $0^{\circ}$ to $100^{\circ} \mathrm{C}$. The various cuts, besides giving the temperature characteristics desired, are also selected, and the dimensions of the crystal chosen, so that there will be only one mode of vibration of fundamental or harmonic frequency in the neighbourhood of the frequency at which the crystal is to be operated.

\section{THE 'MICROTIMER'}

$\mathrm{A}^{\mathrm{N}}$ $N$ electronic timing device called the 'Microtimer' has been produced by R. K. Dundas, Ltd., The Airport, Portsmouth. This measures the time interval between the making, or alternatively, the breaking, of two electrical contacts, or between any other combination of contacts. In addition it may be operated, without contacts, by a suitable valve amplifier in conjunction with, for example, a photo-electric cell. The time indication is given by the position of a pointer moving over the dial of a meter, and the standard instrument has ranges covering 10 to 1,000 milliseconds for full-scale deflexion. It operates entirely from the standard A.c. mains, although a battery model is available. Tests show that the instrument has negligible zero drift, is simple to calibrate and use and is of rugged construction. After taking a measurement, the deflexion of the meter is maintained for several minutes without appreciable drift; throwing a switch brings the meter back to zero for the next measurement. The accuracy claimed is within \pm 2 per cent of the full scale deflexion on any range, even allowing for violent changes in mains voltage or changes of the valves.

The principle of the circuit, which incorporates patented features, may be briefly described. A condenser is charged up from the high-tension supply, and at the beginning of the interval to be timed, the energy in this condenser is allowed to flow through a constant-current pentode valve into a precision condenser. At the end of the timed interval this current is stopped, and the voltage which has been built up across the precision condenser is measured by means of a high-impedance valve voltmeter, to which the output meter is connected, this meter being, of course, calibrated in milliseconds. A voltage stabilizer in the high-tension supply and the provision of considerable negative-feedback assist in maintaining the accuracy of calibration and freedom from drift.

The 'Microtimer', although designed as a laboratory instrument, may be readily operated in routine work by unskilled personnel, and may have a large variety of applications, such as timing the operation of relays, switches, fuses, contact breakers, camera shutters and automatic machinery of all kinds, and in radio, physical and explosives research.

\section{FORTHCOMING EVENTS}

\section{Monday, May 15}

ROYaI COLLEgE OF SURGEONS OF ENGLAND (at Lincoln's Inn Fields, London, W.C.2), at 4 p.m.--Prof. John Beattie: "Clinical Aspects of Methionine Metabolism;".

RoYal Geographioal Societr (at Kensington Gore, London, S.W.7), at 5 p.m.-Dr. Olaf Devik: "The Formation of Ice in Lakes and Rivers". INSTITUTION OF ELECTRICAL ENGINEERS (LONDON STUDENTS'
SECTION) (at Savoy Place, Victoria Embankment, London, W.C.2), at 7 p.m. - Annual General Meeting.

Tuesday, May 16

ROYAL ANTHROPOLOGICAL INSTrTuTE (at 21 Bedford Square, London, W.C.1), at 1.30 p.m.- -Lieut. Bernard Mishkin: "The Indians of the Andes".

Wednesday, May 17

Grological Soctety of LondoN (at Burlington House, Piccadilly, London, W.1), at 3 p.m.- Scientific Papers.

ROYAI COLLEGE OF SURGEONS OF ENGLAND (at Iincoln's Inn Fields, London, W.C.2), at 4 p.m.-Prof. John Beattie: "Clinical Aspects of Methionine Metabolism".

ZOOLOGICAL SocIETY OF LONDON (at Regent's Park, London, N.W.8), at 4.30 p.m.-Exhibition of a Soviet Film on "Animal Life in the Kara-Kum Desert", with commentary by Dr. Edward Hindle, F.R.S. Dr. Ruth Deansley: Demonstration of the Breeding Habits and Life-cycle of Xenopus; Mr. G. P. Wells : "The Parapodia of Arenicole marina L. (Polychæta)". INSTituTroN of ELECTRICAL ENGINEERS (WIRELESS SECTION) (at
Savoy Place, Victoria Embankment, London, W.C.2), at 5.30 p.m.Savoy Place, Victoria Embankment, London, W.C.2), at 5.30 p.m.-
Mr. R. B. Armstrong and Mr. J. A. Smale: "High Speed Recording Mr. R. B. Armstrong and Mr.
of Radio-Telegraph Signals".

INSTITUTE of WELDING (joint meening with the INSTITUTE OF THE PLASTICS INDUSTRY) (at the Institution of Civil Engineers, Great George Street, Westminster, London, S.W.1), at 6 p.m.-Dr. J. H. Paterson: "The Welding of Plastics".

BRITISH INSTITUTION OF RADIO ENGINEERS (MIDLAND SECTION) (at the University (Latin Theatre), Edmund Street, Birmingham), at 6.30 p.m.-Dr. Emrys Williams : "Relaxation Oscillators and Trigger Circuits".

Thursday, May 18

ROYal SOCIETY OF ARTS (DOMINIONS AND COLONIES SECTION) (at John Adam Street, Adelphi, London, W.C.2), at 1.45 p.m.-Mr. H. C. Waite : "African Art". 